ISTIGHNA, Vol. 2, No 1, Januari 2019 P-ISSN 1979-2824

Homepage: http://e-journal.stit-islamic-village.ac.id/index.php/istighna

Aprianif

Pubertas Prekoks Menurut Hukum Islam

(Analisis Konsep Taklif)

\title{
PUBERTAS PREKOKS MENURUT HUKUM ISLAM (Analisis Konsep Taklif)
}

\author{
Aprianif \\ (aprianif@gmail.com) \\ Dosen Sekolah Tinggi Ilmu Tarbiyah (STIT) Islamic Village Tangerang
}

\begin{abstract}
Abstrak: Permasalahan yang diangkat dalam penelitian ini adalah konsep taklif bagi penderita pubertas prekoks. Penelitian ini mendukung pendapat Ibn Qayyim al-Jauziyyah, Muhammad Abu Zahrah dan Subhi Mahmasani yang mengatakan bahwa perubahan dalam hukum Islam biasa terjadi. Hukum Islam bisa berubahubah dengan berbedanya keadaan, tempat dan waktu. Sekaligus menolak pendapat Abid Muhammad as-Sufyani dan Muhammad Muslehuddin yang mengatakan bahwa hukum Islam tidak dapat berubah-ubah. Sumber yang dipakai dalam penelitian ini adalah buku-buku yang berhubungan dengan konsep taklif, dewasa dini dan perubahan-perubahan hukum dalam hukum Islam dengan menjadikan data primernya berupa kitab I'lam al-Muwaqi'in 'an Rabbil 'Alamin karangan Ibn Qayyim al-Jauziyah. Penelitian ini merupakan penelitian kepustakaan. Pendekatan yang digunakan adalah pendekatan sosiologi hukum milik Ibn Qayyim alJauziyyah yang mengatakan bahwa hukum bisa berubah-ubah dengan berubahnya keadaan, waktu dan tempat.
\end{abstract}

Kata kunci: Taklif, Perubahan Hukum, Pubertas Prekoks.

\section{A. Pendahuluan}

Pubertas merupakan salah satu periode penting dalam perjalanan kehidupan manusia. Suatu proses alami yang hampir pasti dialami oleh setiap manusia. Waktunya tidak lama, terjadi antara akhir masa kanak-kanak dengan permulaan masa remaja. $^{255}$

Ketika masa ini datang, maka terjadi perubahan fisik pada diri manusia, dari yang mulanya bertubuh layaknya anak-anak menjadi bertubuh layaknya orang dewasa dan iapun akan memiliki kemampuan untuk bereproduksi. Proses ini sekaligus juga menandai peningkatan kematangan psikologis manusia tersebut yang secara sosial disebut dengan telah menjadi seorang yang sudah dewasa. ${ }^{256}$

Pubertas umumnya dialami oleh manusia ketika ia berusia sekitar sebelas sampai enam belas tahun. Untuk anak perempuan antara usia sebelas sampai lima

\footnotetext{
${ }^{255}$ Jhon W Santrock, Remaja, Edisi Kesebelas (Jakarta: Erlangga, 2007), 83. Diterjemahkan oleh Benedictine Widyasinta dengan judul asli Adolescence, Eleventh Edition.

${ }^{256}$ Mayo Clinic Staff, "Precocious Puberty", Mayo Foundation, Diunduh 12 Desember 2012 dari http://mayoclinic.com/article/precociouspuberty-definition. December $12^{\text {th }} 2012$.
} 
ISTIGHNA, Vol. 2, No 1, Januari 2019 P-ISSN 1979-2824

Homepage: http://e-journal.stit-islamic-village.ac.id/index.php/istighna

Aprianif

Pubertas Prekoks Menurut Hukum Islam

(Analisis Konsep Taklif)

belas tahun dan untuk anak laki-laki usia dua belas sampai enam belas tahun. Tetapi ini hanyalah sebatas teori saja, karena pada kenyataannya pertumbuhan dan perubahan yang terjadi pada diri manusia, bisa berbeda-beda tergantung kepada individunya. Karena memang pubertas sebenarnya dipengaruhi oleh banyak hal, seperti keturunan, lingkungan, gizi, kesehatan dan tekanan emosional. ${ }^{257}$

Kemudian selanjutnya dalam pubertas ini dapat pula terjadi kelainankelainan, berupa pubertas tarda (delayed puberty) dan pubertas prekoks (precocious puberty). Dikatakan pubertas tarda, apabila seseorang belum mencapai pubernya padahal usianya sudah mencapai 18 tahun. ${ }^{258}$ Sebaliknya, ketika manusia tersebut mendapati pubernya di usianya yang sangat muda, sebelum usia 8 atau 9 tahun, maka itu disebut dengan pubertas prekoks. ${ }^{259}$ Penyebabnya bisa bermacam-macam. Bisa karena dipicu oleh otak secara spontan atau bisa juga karena adanya pengaruh dari luar tubuh manusia. Prosesnya, biasanya dimulai diakhir masa kanak-kanak yang ditandai dengan munculnya tanda-tanda kematangan organ reproduksi lebih awal dan dengan telah berakhirnya masa pertumbuhan. ${ }^{260}$

Di Indonesia fenomena pubertas prekoks ini, dulunya tidak begitu diperhatikan. Tetapi belakangan, sekitar 20 sampai 30 tahun terakhir, ia mulai sering disebut-sebut dan menjadi topik-topik utama di kalangan para orang tua, terutama ibu-ibu. Salah satu yang paling sering membicarakan fenomena pubertas

${ }^{257}$ FJ Monks, AMP Knoers, Siti Rahayu Haditono, Psikologi Perkembangan: Pengantar Dalam Berbagai Bagiannya (Yogyakarta: Gadjah Mada University Press, 2002), 263.

${ }^{258}$ Salah satu tanda puber bagi perempuan adalah menarche. Menarche adalah menstruasi kali pertama, yaitu keluarnya cairan darah dari alat kelamin wanita karena luruhnya lapisan dinding dalam rahim yang banyak mengandung pembuluh darah. Menstruasi atau yang biasa disebut dengan haid ini, itu mengacu pada pengeluaran secara periodik darah dan sel-sel tubuh dari vagina yang berasal dari dinding rahim wanita, yang biasanya itu dimulai saat pubertas dan sekaligus menjadi tanda bahwa perempuan tersebut sudah mampu untuk mengandung anak. Lihat Proverawati A dan Misaroh S, Menarche menstruasi pertama yang penuh makna (Yogyakarta: Muha Medika, 2009), 21.

${ }^{259}$ Pubertas tarda adalah sebuah peristiwa dimana seseorang wanita telah mencapai usia 18 tahun namun belum juga mendapatkan haid. Secara khusus untuk anak perempuan batasan pubertas tarda itu adalah apabila belum ada perkembangan payudaranya setelah 5 tahun menarche atau belum menarche pada usia 16 tahun (amenore primer). Lihat Usman Said, "Interaksi Hormonal dan Kualitas Kehidupan Pada Wanita", Diseminarkan pada simposium pengaruh hormonal pada kualitas kehidupan, Dies natalis FK UNSRI ke 42, Palembang 2 Oktober 2004.

${ }^{260}$ Behrman RE, Kliegman RM, Jenson HB, Nelson Textbook of Pediatrics, Edisi 17 (Philadelphia: Saunders Elsevier Science, 2004) 1926-1935. Kemudian dijelaskan oleh Haslam RHA dalam bab Endokrine System. 
ISTIGHNA, Vol. 2, No 1, Januari 2019 P-ISSN 1979-2824

Homepage: http://e-journal.stit-islamic-village.ac.id/index.php/istighna

Aprianif

Pubertas Prekoks Menurut Hukum Islam

(Analisis Konsep Taklif)

prekoks ini adalah Julia Maria van Tiel dan kawan-kawannya melalui mailing list anakberbakat@yahoogroup.com. Bahkan salah satu dari kelompok ibu-ibu yang menamakan diri mereka We R Mommies Indonesia sudah menerbitkan beberapa buku tentang pubertas prekoks, hasil dari seminar-seminar yang telah mereka lakukan. $^{261}$

Ketika masalah pubertas prekoks mulai dibicarakan terutama di dunia-dunia online, belakangan juga muncul banyak penelitian tentang adanya penurunan usia dalam masalah pubertas seorang anak. Baik itu menstruasi pada anak perempuan ataupun keluar mani pada anak laki-laki, walaupun kadang memang mereka tidak menyebutnya dengan pubertas prekoks tetapi sebenarnya sama saja tidak jauh berbeda. Salah satu peneliti tersebut adalah Ginarhayu. Beliau mengatakan bahwa seiring berjalannya waktu belakangan ini telah terjadi penurunan usia pubertas pada diri anak-anak, yaitu dari usia sebelas sampai enam belas tahun menjadi usia sekitar delapan sampai tiga belas tahun. Menurut beliau itu semua diduga karena adanya dua faktor. Faktor endogen dan faktor eksogen. Faktor endogen adalah berupa genetik dan faktor eksogen adalah berupa ekonomi keluarga, status sosial, status gizi, keadaan keluarga, keadaan tempat tinggal, kegiatan fisik dan keterpaparan mereka anak-anak terhadap media massa orang dewasa. ${ }^{262}$

Pada tahun 2007 seorang peneliti lain bernama Burhanuddin juga melakukan penelitian tentang sebuah fakta menarche. Beliau melakukannya di Propinsi Sulawesi Selatan. Hasilnya adalah dari 400 orang pelajar putri Bugis kota dan desa yang ia teliti, ternyata yang sudah menarche itu berusia antara 10,62 tahun sampai 15,71 tahun. Fakta menarik dari penelitiannya adalah dari 200 orang kelompok kota yang beliau teliti, mereka itu mengalami menarche rata-rata pada

${ }^{261}$ Agnes Tri Harjaningrum Dkk, Peranan Orang Tua Dan Praktisi Dalam Membantu Tumbuh Kembang Anak Berbakat Melalui Pemahaman Teori Dan Tren Pendidikan (Jakarta: Prenada Media Group, 2007), lihat di kata pengantar. Kemudian lihat juga sekapur sirih dari Julia Maria van Tiel dalam buku Julia Maria van Tiel, Anakku Terlambat Bicara (Anak Berbakat dengan Disinkronitas Perkembangan: Memahami, Mengasuhnya, Membedakannya dengan Autisme, ADHD, dan Permasalahan Gangguang Belajar), Edisi 1, Cet 2 (Jakarta: Prenada Media Group, 2008).

${ }^{262}$ Ginarhayu, "Analisis Faktor-Faktor Yang Berhubungan Dengan Usia Menarche Remaja Putri (9 - 15 Tahun) Pada Siswi Sekolah Dasar dan Sekolah Lanjutan Tingkat Pertama di Jakarta Timur", 2001. Tesis Ginarhayu di Universitas Indonesia. Lihat http://www.digilib.ui.edu/opac/themes/libri2/detail.jsp?id=71129\&lokasi=lokal. 
ISTIGHNA, Vol. 2, No 1, Januari 2019 P-ISSN 1979-2824

Homepage: http://e-journal.stit-islamic-village.ac.id/index.php/istighna

Aprianif

Pubertas Prekoks Menurut Hukum Islam

(Analisis Konsep Taklif)

usia 12,93 tahun. Sedangkan kelompok desa itu mengalami menarche pada usia rata-rata 13,18 tahun. Kesimpulannya adalah ditemukan adanya perbedaan usia menarche pada putri Bugis yang berada di kota dengan putri Bugis yang ada di desa. $^{263}$

Lain dengan Burhanuddin, lain lagi dengan Pebri Warita Pulungan. Ia juga melakukan penelitian tentang fakta menarche. Ia melakukannya di dua SMP di kota Medan pada tahun 2009. Dua SMP yang ia teliti adalah SMP Shafiyyatul Amaliyah dan SMP Nurul Hasanah. SMP Shafiyyatul Amaliyah mewakili kelompok siswa dengan ekonomi menengah keatas dan sebaliknya SMP Nurul Hasanah mewakili kelompok siswa dengan ekonomi menengah kebawah. Hasilnya adalah usia menarche rata-rata di SMP Shafiyyatul Amaliyah adalah 11,45 tahun dan usia menarche rata-rata di SMP Nurul Hasanah adalah 12,19 tahun. Usia menarche termuda terdapat di SMP Shafiyyatul Amaliyah dengan usia 8 tahun dan usia menarche tertua terdapat di SMP Nurul Hasanah dengan usia 14 tahun. Kesimpulannya adalah bahwa faktor ekonomi keluarga cukup berpengaruh terhadap percepatan usia menarche seorang anak. ${ }^{264}$

Dewasa ini memang masalah percepatan usia pubertas, merupakan salah satu fenomena yang cukup menarik untuk dikaji. Dalam sebuah penelitian tentang remaja Inggris dikatakan bahwa telah terjadi penurunan rata-rata usia menarche selama 20 sampai 30 tahun terakhir. ${ }^{265}$ Saat ini di Amerika Serikat dikatakan bahwa remaja putrinya itu mengalami menarche lebih cepat 9 bulan dari generasi 20 tahun yang lalu. Bahkan dikatakan kecendrungan seperti ini akan terus menerus berlansung sejak dimulai pada akhir abad ke 19. Faktanya juga $10 \%$ dari

\footnotetext{
${ }^{263}$ Sudirman Burhanuddin, "Beberapa Variabel yang Berpengaruh terhadap Usia Menarche Pelajar Putri Bugis Kota dan Desa di Sulawesi Selatan (Suatu Pendekatan Antropologi Ragawi Ditinjau dari Aspek Biologis dan Lingkungan Tahun 2007". Tesis Sudirman Burhanuddin di Unair. Lihat http://www.adln.lib.unair.ac.id/.

${ }^{264}$ Pebri Warita Pulungan, "Gambaran Usia Menarche Pada Remaja Putri di SMP Shafiyyatul Amaliyah dan SMP Nurul Hasanah Kota Medan Tahun 2009". Fakultas Kedokteran Universitas Sumatra Utara http://repository.usu.ac.id/bitstream/123456789/14263/1/09E02903.pdf.

${ }^{265} \mathrm{PH}$ Whincup, JA Ghil, K Odoki, Taylor SDC, DG Cook, "Age of Menarche in Contemporary British Teenagers: Survey of Girls Born Between 1982 and 1986" (BMJ: 2001), 322:1095-1096. Lihat http://www.ncbi.nlm.nih.gov/pmc/articles/PMC31261/.
} 
ISTIGHNA, Vol. 2, No 1, Januari 2019 P-ISSN 1979-2824

Homepage: http://e-journal.stit-islamic-village.ac.id/index.php/istighna

Aprianif

Pubertas Prekoks Menurut Hukum Islam

(Analisis Konsep Taklif)

anak-anak kulit putih dan $15 \%$ dari anak-anak kulit hitam itu mengalami menarche dini. ${ }^{266}$

Munculnya fenomena ini di kehidupan masyarakat, keberadaan pubertas prekoks serta terjadinya pergeseran usia dalam masalah pubertas seorang anak menimbulkan banyak pertanyaan. Baik itu di kalangan akademisi hukum ataupun masyarakat luas terutama bagi kaum Muslimin (orang-orang yang menganut agama Islam), karena di dalam agama Islam hal ini sangat erat kaitannya dengan konsep pendidikan Islam dan pembebanan hukum (taklif) dalam hukum Islam. ${ }^{267}$

Belum lagi jika ada anak-anak yang mensruasi (menarche) ataupun keluar air mani diusia yang sangat-sangat dini (dibawah usia tujuh tahun umpamanya). Dikatakan bahwa dalam suatu kasus, pernah ada seorang anak yang menarche diusia enam tahun, bahkan ada yang dibawah itu. Diceritakan bahwa pernah ada seorang anak yang sudah hamil diusia lima tahun. Pertanyaannya, kapan menarche-nya terjadi? Jawabannya, mungkin saja diusia sekitar 6 bulan sampai 3 tahun. Pertanyaan berikutnya, bagaimana taklifnya? ${ }^{268}$

Untuk menjawab pertanyaan yang menganjal itulah penulis berusaha mengkaji ulang dan mengangkat permasalahan ini kembali. Penulis berusaha menghubungkan fenomena yang terjadi ini dengan berbagai perubahan-perubahan hukum yang terjadi dalam hukum Islam, terutama yang berkaitan dengan masalah

${ }^{266}$ B Nazario, "WebMD Medical News", Vol 24 (Cadernos De Saude Publica: 2002).

${ }^{267}$ Kata taklif berasal dari bahasa Arab, mustaq (diambil) dari fi'il madi kallafa. Dalam Islam ia digunakan sebagai sebuah istilah yang berkaitan dengan pembebanan dan pertanggungjawaban hukum yang terdapat dalam hukum Islam. Lihat Abdullah Ibn Ahmad Ibn Qudamah, Raudah an-Nadir (Riyad: Jami'ah al-Imam Muhammad Ibn Su'ud, 1399 H), 46-47.

Selanjutnya perlu diketahui juga bahwa walaupun kata taklif berasal dari bahasa Arab, tetapi sekarang ia juga sudah menjadi bahasa Indonesia, sudah masuk dalam KBBI. Lihat Kamus Besar Bahasa Indonesia http://bahasa.kemdiknas.go.id/kbbi/index.php

${ }^{268}$ Dalam Detik Health edisi 2011 dikatakan bahwa Dr Edmundo Escomel pernah melaporkan ke La Presse Medicale bahwa Lina Medina benar-benar merupakan ibu termuda dalam sejarah, ia merupakan ibu kandung dari Gerardo. Ia mengalami menarche pada usia 8 bulan, perkembangan payudaranya pada usia 4 tahun, pelebaran tulang panggul dan pematangan tulang serta melahirkan pada usia 5 tahun.

Awalnya memang kejadian ini terdengar agak aneh, tapi pada kelanjutannya ia bisa diterima dalam kajian ilmiyah. Karena bisa jadi Lina Medina merupakan salah satu dari penderita pubertas prikoks parsial. Pubertas prekoks parsial adalah sebuah pubertas yang gejalanya terjadi sangat lebih awal. Umumnya mulai muncul keluhannya sekitar usia 6 bulan sampai 3 tahun yang itu ditandai dengan terjadinya pembesaran payudara dan kemudian akan berhenti atau tetap bertahan tanpa perubahan fisik. http://health.detik.com/read/2011/11/24/123350/1774689/1202/ibu-termuda-dalam-sejarahmelahirkan-saat-usia-5-tahun. 
ISTIGHNA, Vol. 2, No 1, Januari 2019 P-ISSN 1979-2824

Homepage: http://e-journal.stit-islamic-village.ac.id/index.php/istighna

Aprianif

Pubertas Prekoks Menurut Hukum Islam

(Analisis Konsep Taklif)

hukum dan "sosial change". Penulis akan menghubungkannya dengan teori elastitas dan eternalitas dalam hukum Islam. Karena itu, penilitian ini sangat penting menurut penulis, agar masyarakat tidak bingung dan muncul keraguan dihati mereka dan semboyan Islam sebagai agama rahmat yang dianggap mampu menjawab segala perkembangan zaman benar-benar terbukti, dan selogan Islam sebagai agama yang sempurna dimata masyarakat dunia itu benar-benar terwujud, tidak hanya sekedar obrolan semata. ${ }^{269}$

\section{B. Mengenal Pubertas dan Pubertas prekoks}

Berbicara mengenai pubertas, pubertas adalah suatu istilah yang berasal dari bahasa latin (pubescere) yang artinya adalah mendapatkan pubes atau rambut kemaluan, yaitu suatu tanda kelamin sekunder yang menunjukkan perkembangan seksual seseorang. Istilah ini dipakai atau dimaksudkan untuk remaja sekitar masa pemasakan seksual. ${ }^{270}$ Dulu Nabi Muhammad Saw menggunakan konsep ini untuk membedakan mana seseorang yang sudah dewasa dan mana yang masih anak-anak. $^{271}$

Pubertas merupakan suatu tahap penting dalam proses tumbuh kembang seseorang. Perkembangan ciri-ciri seksual sekunder, perubahan komposisi tubuh, perubahan maturasi tulang, menutupnya epifisis dan terbentuknya perawakan akhir dewasa terjadi pada masa ini, dan ini semua disebabkan karena adanya perubahan hormonal yang hanya berlangsung pada masa pubertas. Karena itu pubertas sebenarnya merupakan suatu proses biologis kompleks yang kelansungannya terjadi dalam beberapa tahap dan dipengaruhi oleh beberapa faktor seperti genetik, nutrisi, lingkungan, sosial dan ekonomi. Faktor-faktor

\footnotetext{
${ }^{269}$ Didin Hafidhudin, Islam Aplikatif (Jakarta: Gema Insani Press, 2003), 147-148.

${ }^{270}$ Aliyah B Purwakania Hasan, Psikologi Perkembangan Islami (Jakarta: PT RajaGrafindo Persada, 2008), 109.

${ }^{271}$ Lihat Hadist Rasulullah Saw ketika perang Bani Quraizah yang artinya "diriwayatkan oleh At-Tiyah Al-Qurazi, dia berkata "Kami telah dihadapkan kepada Nabi Saw pada perang Bani Quraizah. Barangsiapa yang telah tumbuh (rambut kemaluannya), maka dia dibunuh, dan barangsiapa yang belum tumbuh (rambut kemaluannya), maka dia akan tetap hidup. Dan aku merupakan salah seorang dari mereka yang dibiarkan hidup." Hadist riwayat at-Tirmidhi dan anNasai. Lihat Abu 'Isha at-Tirmidhi, Sunan at-Tirmidhi (Beirut: Dar al-Kutub al-'Ilmiyyah, t.thn), Hadist ke 1584, 1125.
} 
ISTIGHNA, Vol. 2, No 1, Januari 2019 P-ISSN 1979-2824

Homepage: http://e-journal.stit-islamic-village.ac.id/index.php/istighna

Aprianif

Pubertas Prekoks Menurut Hukum Islam

(Analisis Konsep Taklif)

inilah yang bertanggung jawab atas awitan dan perkembangan seorang manusia guna menuju maturitas seksual yang lengkap. ${ }^{272}$

Pubertas merupakan suatu tahapan dalam proses pertumbuhan dan perkembangan kontinu. Pada saat pubertas ini terjadi akan terjadi pacu tumbuh, tercapai fertilitas, munculnya perubahan kognitif dan psikologis, ada perubahan morfologis dan fisiologis serta tidak ketinggalan juga akan terjadi maturasi dari sistem reproduksi yang timbul karena adanya perubahan aktivitas endokrin secara sekuensial dan teratur. ${ }^{273}$

Tetapi selanjutnya, sebagaimana disebutkan dimuka dalam prosesnya pubertas ini tidak senantiasa berjalan normal. Sering terjadi kelainan-kelainan. Secara umum ada dua macam kelainan yaitu pubertas dini atau pubertas prekoks (inti dari penelitian ini) dan pubertas tarda atau pubertas terlambat. ${ }^{274}$

Pubertas dikatakan sebagai pubertas prekoks atau precocious puberty apabila tanda pubertas seseorang muncul lebih awal dari biasanya. Bila biasanya pubertas itu dimulai antara usia 11 sampai 15 tahun pada anak perempuan dan usia 12 sampai 16 tahun pada anak laki-laki, maka pada pubertas prekoks, anak perempuan akan mengalami gejala pubertas atau mendapati tanda pubertasnya pada usia kurang dari 8 tahun dan anak laki-laki pada usia kurang dari 9 tahun. ${ }^{275}$ Hal ini sebenarnya bisa merupakan bagian dari variasi perkembangan yang normal, namun bisa juga merupakan penyakit atau pertumbuhan hormon yang tidak normal. $^{276}$

Anak-anak yang menderita pubertas prekoks ini biasanya mengalami beberapa masalah. Salah satunya adalah masalah tinggi badan. Biasanya tinggi

\footnotetext{
${ }^{272}$ Aliyah B Purwakania Hasan, Psikologi Perkembangan Islami, 111.

${ }^{273}$ Elizabeth B Hurlock, Psikologi Perkembangan: Suatu pendekatan Sepanjang Rentang Kehidupan, Edisi 5, (Jakarta: Erlangga, 1980), 206.

${ }^{274}$ Behrman RE, Kliegman RM, Arvin AM, Nelson, Ilmu Kesehatan Anak, Vol III, Edisi XV (Jakarta: EGC, 2002), 1925-1934. Diedit oleh A Samik Wahab.

${ }^{275}$ Delemarre Van de Waal, Central Regulation of Human Puberti, Disertasi di Vrije Universiteit te Amsterdam, 1984. Lihat juga Jose RL Batubara, Adolescent Development (Perkembangan Remaja), Departemen Ilmu Kesehatan Anak RSCM dan Universitas Indonesia, Seri Pediatri, Vol XII, No I, Juni 2010. http://www.scribd.com/doc/244707171/jurnal-pubertasnormal-pdf\#scribd.

${ }^{276} \mathrm{JL}$ Fahmi, JK Kaminsky, F Kaufman, MD Nelson, MT Parisi, The Radiological Approach to Precocious Puberty, The British Journal of Radiology, Vol 73, 560-567, 2000. Diakses dari http://bjr.birjournals.org/cgi/reprint/73/869/560.pdf.
} 
ISTIGHNA, Vol. 2, No 1, Januari 2019 P-ISSN 1979-2824

Homepage: http://e-journal.stit-islamic-village.ac.id/index.php/istighna

Aprianif

Pubertas Prekoks Menurut Hukum Islam

(Analisis Konsep Taklif)

badan mereka akan abnormal (tidak normal). Awalnya memang mereka ini kelihatan memiliki tinggi badan lebih tinggi dibandingkan dengan anak-anak seusianya. Tetapi pada kelanjutannya karena maturasi tulangnya lebih awal dan cakram episifisnya menutup lebih cepat, maka pertumbuhan mereka berhenti lebih cepat juga. Inilah alasannya kenapa anak-anak pubertas prekoks memiliki tinggi badan lebih rendah dari yang seharusnya mereka miliki dan tubuh mereka biasanya akan lebih pendek dibandingkan dengan teman-teman seusianya ketika telah mencapai usia dewasa. ${ }^{277}$

Selain masalah tinggi badan, biasanya mereka juga memiliki masalah sosial dan emosional. Mereka biasanya akan menunjukkan perubahan suasana hati seperti lekas marah dan suka murung pada anak perempuan dan menjadi agresif serta dimulainya perjalanan seks yang tidak tepat pada anak laki-laki. Perubahanperubahan yang terjadi pada diri mereka ini membuat mereka menjadi agak berbeda jika dibandingkan dengan anak-anak sebayanya. Tidak jarang banyak diantara mereka yang merasa malu dengan perubahan-perubahan tersebut, terutama anak perempuan (karena pertumbuhan payudaranya). Hal ini pada akhirnya menjadikan mereka kurang percaya diri dan akan meningkatkan resiko terjadinya depresi. ${ }^{278}$

Sampai sekarang penyebab pasti dari pubertas prekoks ini masih belum diketahui. Tetapi secara umum dikatakan bahwa dalam keadaan yang jarang penyebabnya adalah karena meningkatnya produksi steroid. Peningkatan produksi steroid ini bisa terjadi karena beberapa hal. Diantaranya adalah karena meningkatnya sekresi hormon gonadotropin, penyakit intrinsik adrenal (ovarium atau testis), penyakit pada otak ataupun tumor yang menghasilkan hormon

\footnotetext{
${ }^{277}$ Styne DM, Puberty, Dalam Greenspan FS, Basic and Clinical Endrocrinology 3, Edisi III, (San Fransisco: Lange, 1992), 519-540.

${ }^{278}$ Tanda-tanda seksual sekunder itu diantaranya adalah pada anak perempuan, pertumbuhan payudara, rambut di kemaluan, jerawat dan menstruasi. Untuk anak laki-laki tanda-tandanya adalah pembesaran testis dan penis, rambut di kemaluan dan ketiak, suara yang dalam dan jerawat. Apabila tanda-tanda ini muncul sebelum umur 8 tahun pada anak perempuan dan umur 9 tahun pada anak laki-laki, maka bisa disimpulkan bahwa anak tersebut terkena gejala pubertas prekoks. Batasan umur dalam pubertas prekoks ini sebenarnya sudah disandarkan pada awitan pubertas pada populasi normal. Tentu dengan sudah mempertimbangkan berbagai hal seperti ras, jenis kelamin, kondisi nutrisi, dan secular trend. Lihat Jose RL Batubara, Gonadothropin-releasing hormone agonist as a treatment of choice for central precocious puberty, Pediatric Endocrinology, Pediatric Department FKUI - RSCM, Jakarta, November 2004, Vol 19, No 4
} 
ISTIGHNA, Vol. 2, No 1, Januari 2019 P-ISSN 1979-2824

Homepage: http://e-journal.stit-islamic-village.ac.id/index.php/istighna

Aprianif

Pubertas Prekoks Menurut Hukum Islam

(Analisis Konsep Taklif)

reproduksi. Selain itu faktor psikologis dan stressor lingkungan ekternal dikatakan biasanya juga cukup memberi peran. ${ }^{279}$

Untuk bisa lebih mengenali pubertas prekoks, maka perlu diketahui manifestasi klinisnya. ${ }^{280}$ Apabila tanda-tanda klinis ini terjadi pada anak perempuan ataupun anak laki-laki dan dialami pada usia kurang dari 9 tahun pada anak perempuan dan usia 10 tahun pada anak laki-laki, maka bisa jadi mereka terjangkit gejala pubertas prekoks. Tanda-tanda klinisnya pada anak perempuan adalah (1) Payudara membesar, (2) Tumbuhnya rambut pubis, (3) Tumbuhnya rambut tipis pada lengan bawah, (4) Bertambahnya tinggi dengan cepat, (5) Munculnya menstruasi, (6) Tumbuhnya jerawat dan terakhir (7) Munculnya bau badan. Sedangkan pada anak laki-laki, manifestasi klinisnya adalah (1) Mengalami pembesaran testis dan penis, (2) Tumbuhnya rambut pubis, (3) Tumbuhnya rambut di lengan bawah dan wajah, (3) Peningkatan tinggi badan dengan cepat, (4) Suara mulai memberat, (5) Tumbuhnya jerawat dan (6) Munculnya bau badan. ${ }^{281}$

${ }^{279}$ Haslam RHA, Endokrine System, Dalam Behrman RE, Kliegman RM, Jenson HB, Nelson Textbook of Pediatrics, Edisi XXVII (Philadelphia: Saunders Elsevier Science, 2004), 1926-1935.

${ }^{280}$ Paul B Kaplowitz, Precocius Puberty, Medscape Team of Medician, diakses 2 September 2015. Lihat http://emedicine.medscape.com/article/924002-overview

${ }^{281}$ Selain dua tipe pubertas prekoks diatas, sebenarnya adalagi pubertas prekoks yang lain yaitu pubertas prekoks parsial. Pubertas prekoks parsial adalah sebuah pubertas yang mana gejala pubertasnya terjadi antara usia 6 bulan sampai 3 tahun. Pada anak perempuan bisa dikenali dengan terjadinya pembesaran payudara pada usia dibawah 3 tahun dan selanjutnya pembesarannya akan berhenti atau akan tetap bertahan seperti itu tanpa perubahan fisik. Tetapi pubertas tipe ini jarang terjadi, makanya tidak dimasukkan kedalam kategori pubertas prekoks. Lihat Paul B Kaplowitz, Precocius Puberty, Medscape Team of Medician, diakses 3 September 2015. Lihat http://emedicine.medscape.com/article/924002-overview.

Selanjutnya ada juga yang menyebut pubertas prekoks parsial ini dengan telars premature, walaupun sebenarnya tidaklah sama. Telars premature pertama kali disebutkan oleh Wilkins untuk payudara yang berkembang saja di usia dibawah tiga tahun tampa ada tanda-tanda pubertas lainnya. Kata Wilkins perkembangan payudara ini bisa di salah satunya, atau kedua-duanya. Dikatakan antara tahun 1945-1975 di Amerika Utara dilaporkan terdapat 205 kasus telars premature. Selanjutnya pada tahun 1981 di Puer to Rico dikatakan telah terjadi 482 kasus telars premature. Rogriguez mengatakan itu semua terjadi akibat mengkosumsi makanan dan minuman berupa daging ayam, sapi, babi dan susu yang mengandung preparat estrogen. Selanjutnya di Sub bagian Endokrinologi Anak dan Remaja FKUI/RSCM dari tahun 1987-1991 tercatat ada 682 kasus endoktri dan 53-nya dikatakan adalah kasus telars premature. Lihat Lihat R Roman, MC Jhonson, E Codner, MA Boric, A Avila, F Cassoria, Activating GNAS gene Metation in Patient Wich Premature Telars, J Pediatr, 2004, 145: 1-8. Lihat juga Saenz de Rogdriguez, AM Bongiovanni, Conde de Borrego, Epedemic of Precocius Development in Puerto Rican Children, J Pediart, 1985, 107: 393-396, dan lihat juga MS Assin, Peranan Hormon Dalam Proses Tumbuh Kembang 
ISTIGHNA, Vol. 2, No 1, Januari 2019 P-ISSN 1979-2824

Homepage: http://e-journal.stit-islamic-village.ac.id/index.php/istighna

Aprianif

Pubertas Prekoks Menurut Hukum Islam

(Analisis Konsep Taklif)

\section{Konsep Taklif Dewasa Dini dan Ijtihad Intiqa'i}

Sebagaimana diketahui bersama di dalam terminologi hukum Islam, ada sebuah istilah yang biasa disebut dengan al-mukallaf (yang dibebani hukum) atau dalam istilah lain al-mahkum 'alaih (subjek hukum) yaitu seseorang yang telah dianggap mampu bertindak secara hukum. ${ }^{282}$ Maksudnya adalah apabila seseorang telah mendapatkan prediket mukallaf atau mahkum 'alaihi ini, maka ia sudah harus mempertanggungjawabkan segala perbuatannya di hadapan hukum. ${ }^{283}$

Lalu apa patokan yang dijadikan dasar oleh hukum Islam untuk mengetahui apakah seseorang tersebut sudah mukallaf atau belum. Untuk mengetahui ini perlu dipahami bahwa sebenarnya dalam hukum Islam, prinsipnya ialah ia tidak mau mengenakan pembebanan hukum kepada seseorang sebelum seseorang tersebut mengerti dan paham akan hukum yang diberlakukan kepadanya. Oleh karena itu, di dalam hukum Islam itu ada sebuah ketentuan dasar yaitu fahm al-mukallaf lima kullifa bihi, artinya pengetahuan atau pemahaman subjek hukum terhadap suatu hukum yang diberlakukan kepadanya menjadi sarat utama sebelum ia mempertanggungjawabkannya. ${ }^{284}$

Kemudian selanjutnya bagaimana cara mengetahui bahwa seseorang itu sudah mempunyai fahm al-mukallaf lima kullifa bihi. Jawabannya adalah seseorang bisa dikatakan sudah mempunyai fahm al-mukallaf lima kullifa bihi, apabila ia telah memenuhi beberapa ketentuan yaitu 'aqil (berakal sehat), balig (cukup umur) dan mumayyiz (dapat membedakan baik dan buruk). ${ }^{285}$ Ketika seseorang belum 'aqil, belum balig dan belum mumayyiz, maka biasanya pemahamannya terhadap suatu hukum, belumlah benar-benar sempurna.

Selain itu, seseorang juga belum akan dikenakan pembebanan hukum dalam hukum Islam sebelum ia mendapatkan prediket kelayakan dan kecakapan

Anak dan Remaja, Pidato Pengukuhan Penerimaan Jabatan Guru Besar Tetap Dalam Ilmu Kesehatan Anak Pada Universitas Indonesia, Jakarta, 9 Januari 1993.

${ }^{282}$ Abuddin Nata, Abdur Rahman Dahlan, Muhammad Amin Suma, Ahmad Thib Raya dan kawan-kawan, Ensiklopedi Hukum Islam (Jakarta: PT Ichtiar Baru Van Hoeve, 1999), 1219.

${ }^{283}$ Muhammad Ibn Ali Ibn Muhammad ash-Syaukani, Irshad al-Fuhul ila Tahqiq al-Haq min 'Ilmi al-Usul (Cairo: Dar as-Salam, 2006), 65. Lihat juga Teguh Prasetyo dan Abdul Halim Barkatullah, Politik Hukum Pidana (Yogyakarta: Pustaka Pelajar, 2005), 135-136.

${ }^{284}$ Ash-Shaukani, Irshad al-Fuhul ila Tahqiq al-Haq min 'Ilmi al-Usul, 65. 121.

${ }^{285}$ Wahbah az-Zuhayli, al-Fiqh al-Islami wa Adillatuh, Juz IV (Beirut: Dar al-Fikr, 1989), 
ISTIGHNA, Vol. 2, No 1, Januari 2019 P-ISSN 1979-2824

Homepage: http://e-journal.stit-islamic-village.ac.id/index.php/istighna

Aprianif

Pubertas Prekoks Menurut Hukum Islam

(Analisis Konsep Taklif)

(capability and capacity). ${ }^{286}$ Kelayakan dan kecakapan ini di dalam terminologi hukum Islam dikenal dengan istilah al-Ahliyah. Al-ahliyah itu adalah suatu sifat yang dimiliki oleh seseorang yang dijadikan ukuran oleh syari' (Allah Swt) untuk menentukan apakah ia telah cakap dikenai tuntutan syara' atau belum. ${ }^{287}$ Dalam pengertian lain ia diartikan dengan suatu sifat yang menunjukkan bahwa seseorang telah sempurna jasmani dan akalnya, sehingga secara hukum seluruh tindakannya sudah dapat dipertanggungjawabkannya. ${ }^{288}$

Konsep al-ahliyah ini di dalam ilmu Usul Fiqh itu diklasifikasikan menjadi dua, yaitu al-Ahliyah al-Ada' dan al-Ahliyah al-Wujub. Al-Ahliyah al-Ada' adalah suatu sifat kecakapan bertindak hukum seseorang yang telah dianggap sempurna untuk bisa mempertanggungjawabkan seluruh perbuatannya, baik itu yang bersifat positif ataupun negatif. Wazn atau ukuran dalam al-Ahliyah al-Ada' ini adalah aqil, baligh dan berakal sempurna. Sedangkan al-Ahliyah al-Wujub adalah sifat kecakapan seseorang untuk menerima hak-hak yang menjadi haknya walaupun ia belum cakap untuk dibebani kewajiban hukum. Ia hanya dianggap mampu untuk menerima hak-haknya dan tidak dituntut adanya kewajiban hukum atas dirinya. ${ }^{289}$

Oleh karena itu, ulama Usul Figh (ahli hukum Islam) mengemukakan bahwa dasar pertanggungjawaban hukum dalam hukum Islam itu ringkasnya hanya tiga saja yaitu berakal ('aqil, mumayyiz), cukup umur (balig) dan pemahaman. Artinya seseorang baru bisa dibebani hukum apabila ia berakal, dapat memahami secara baik taklif yang ditujukan kepadanya dan ia sudah cukup umur. $^{290}$

Ketika berbicara tentang ketiga syarat ini, sebenarnya itu agak sedikit sulit dan rumit. Ketiganya sebenarnya adalah suatu hal yang tidak bisa dipisahkan

\footnotetext{
${ }^{286}$ Abdul Hay 'Azb Abdul 'Al, Usul al-Fiqh al-Muyassar, Cet II (Cairo: Universitas Al Azhar, 2006), 183.

${ }^{287}$ Abuddin Nata, Abdur Rahman Dahlan, Muhammad Amin Suma, Ahmad Thib Raya dan kawan-kawan, Ensiklopedi Hukum Islam, 1220.

${ }^{288}$ Abdul Aziz al-Bukhari, Kashf al-Asrar, Jilid II (Beirut: Dar al-Fikr, 1982), 1357.

${ }^{289}$ Abu Hamid al-Ghazali, al-Mustasfa fi 'Ilmu al-Usul, Jilid I (Beirut: Dar al-Kutub al'Ilmiyyah, 1983), 98. Lihat juga Muhibullah Ibn Abdush Shakur, Musallam ats-Tsubut, Jilid I (Beirut: Dar al-Kutub al-'Ilmiyah, 1983), 116.

${ }^{290}$ Abu Bakar Muhammad al-Sarakhsi, Usul al-Sarakhsi, Jilid II (Beirut: Dar al-Kutub al'Ilmiyyah, 1983), 340. Lihat juga Saifuddin al-Amidi, al-Ihkam fi Usul al-Ahkam (Beirut: Dar alKutub al-'Ilmiyyah, 1983), 137.
} 
ISTIGHNA, Vol. 2, No 1, Januari 2019 P-ISSN 1979-2824

Homepage: http://e-journal.stit-islamic-village.ac.id/index.php/istighna

Aprianif

Pubertas Prekoks Menurut Hukum Islam (Analisis Konsep Taklif)

antara satu dengan yang lain. Prinsipnya, pemahaman hanya bisa dicapai melalui akal yang sehat dan akal adalah sesuatu yang tersembunyi dan sulit diukur serta akan berbeda-beda antara satu orang dengan yang lainnya sesuai dengan perkembangan biologisnya. Maka karena itu, hukum Islam kemudian menetapkan patokan dasar sebagai indikasi luar dalam menentukan apakah seseorang tersebut sudah cukup berakal atau belum, sudah cukup mampu memahami syara' atau belum. Indikasi itu adalah balig (cukup umur).

Berbicara tentang balig, ulama Mazhab mempunyai pandangan yang berbeda-beda. Namun walaupun begitu rata-rata semuanya sepakat mengukurnya dengan haid bagi kaum perempuan dan keluar air mani bagi kaum laki-laki atau telah genap berusia 15 tahun menurut mayoritas jumhur ulama. Kemudian mereka juga sepakat mengatakan bahwa untuk tiga batasan ini prinsip yang digunakan adalah mana yang lebih dahulu dicapai atau dipenuhi oleh si anak. ${ }^{291}$

Menurut ulama Hanafiyyah balig bagi laki-laki itu bisa dicapai dengan (1) keluar mani, baik dalam keadaan tidur (ihtilam) ataupun terjaga, karena bersetubuh atau bukan dan (2) menghamili. Tetapi kemudian dua kriteria ini, itu harus diikuti oleh satu kriteria lainnya yaitu ia harus berusia minimal 12 tahun. Sedangkan kriteria untuk perempuan adalah (1) haid dan (2) hamil dengan ketentuan lainnya, mereka harus berusia minimal 9 tahun, dan seandainya karena sesuatu hal, kriteria-kriteria ini tidak muncul maka imam Abu Hanifah (w.150 H) mengatakan bahwa batasan usia yang dipakai adalah bagi laki-laki usia 18 tahun dan bagi perempuan usia 17 tahun. ${ }^{292}$

Ulama Malikiyah mengatakan bahwa kriteria balig itu ada tujuh macam. Lima bagi laki-laki dan perempuan, dua khusus bagi perempuan saja. Kriteria yang khusus bagi perempuan itu adalah (1) haid dan (2) hamil. Sedangkan kriteria yang berlaku bagi laki-laki dan perempuan adalah (1) keluarnya air mani baik dalam keadaan tidur ataupun terjaga, (2) tumbuhnya rambut kemaluan, (3) tumbuhnya rambut ketiak, (4) indra penciuman menjadi peka dan yang terakhir

${ }^{291}$ Abu Abdillah Muhammad Ibn Ahmad al-Qurtubi, al-Jami’ li Ahkam Al-Qur'an, Jilid V (Beirut: Dar al-Fikr, t.thn), 37.

${ }^{292}$ Ibn 'Abidin, Hashiyah Rad al-Mukhtar 'ala Daur al-Mukhtar, Jilid V (Cairo: Al-Bab alHalabi, t.thn), 107. 
ISTIGHNA, Vol. 2, No 1, Januari 2019 P-ISSN 1979-2824

Homepage: http://e-journal.stit-islamic-village.ac.id/index.php/istighna

Aprianif

Pubertas Prekoks Menurut Hukum Islam

(Analisis Konsep Taklif)

(5) perubahan suara. Namun apabila kriteria balig ini tidak muncul maka batasan usia yang mereka pakai adalah usia genap 18 tahun atau usia genap 17 tahun memasuki usia 18 tahun. ${ }^{293}$

Imam As-Sairazi (w.476 H) dan al-Khatib (w.977 H) mengemukakan bahwa di dalam Mazhab Syafi'i balig bagi laki-laki dan perempuan itu dapat dicapai dengan (1) usia anak genap 15 tahun Qomariyah, (2) keluarnya air mani bagi lakilaki dan perempuan di usia yang memungkinkan yaitu minimal usia 9 tahun, (3) dan tumbuhnya rambut di sekitar kemaluan. Sedangkan kriteria balig yang khusus bagi perempuan adalah (1) haid, dan (2) hamil. ${ }^{294}$

Wahbah az-Zuhayli (w.1436 H) pernah menyimpulkan, berdasar berbagai pendapat para ulama Mazhab diatas, menurut pengamatan beliau kriteria balig itu sejatinya hanya ada lima saja. Tiga untuk laki-laki dan perempuan, dua khusus untuk perempuan. Tiga untuk laki-laki dan perempuan itu adalah (1) keluarnya air mani, (2) tumbuhnya rambut kemaluan dan (3) batasan usia tertentu. Sedangkan yang khusus untuk perempuan saja adalah (1) haid dan (2) hamil. ${ }^{295}$

Dalil-dalil yang dipakai dalam masalah balig ini diantaranya adalah surat an-Nur (24) ayat 59, yang artinya: Dan apabila anak-anakmu telah sampai usia balig, maka hendaklah mereka meminta izin, seperti orang-orang yang sebelum mereka meminta izin. Demikianlah Allah menjelaskan ayat-ayat-Nya dan Allah Maha mengetahui lagi Maha Bijaksana.

Kemudian Hadis dari Ibn Umar Ra,

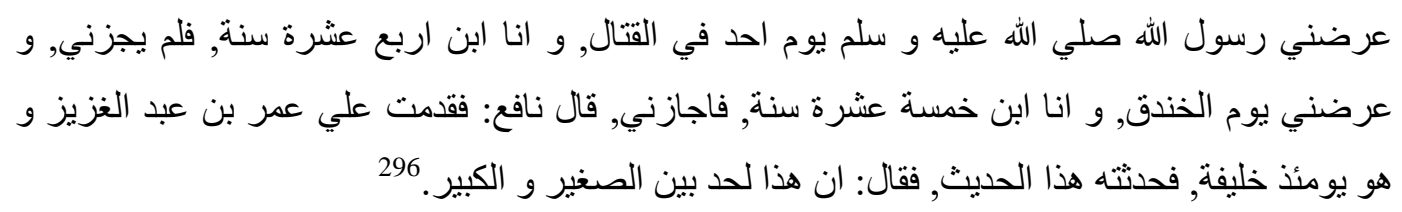

${ }^{293}$ Ad-Dardiri, Al-Sharah al-Kabir Hashiyah Dasuki, Jilid III (Cairo: Matba'ah al-Bab alHalabi, t.thn), 293.

${ }^{294}$ Abu Ishak as-Sairazi, Al-Muhadhdhab, Juz I (Cairo: Mathba'ah al-Bab al-Halabi, t.thn), 330. Lihat juga ash-Sharbini al-Khatib, Mughni al-Muhtaj Sharah al-Minhaj, Juz II (Cairo: Mathba'ah al-Bab al-Halabi, t.thn), 166.

${ }^{295}$ Wahbah az-Zuhayli, al-Fiqh al-Islami wa Adillatuhu, Juz V (Beirut: Dar al-Fikr, 1989), 424 .

${ }^{296}$ Abu Zakariya Muhyuddin An-Nawawi, Sahih Muslim bi Sharah An-Nawawi, Juz XIII (Beirut: Darul Khair, 1994) 12. 
ISTIGHNA, Vol. 2, No 1, Januari 2019 P-ISSN 1979-2824

Homepage: http://e-journal.stit-islamic-village.ac.id/index.php/istighna

Aprianif

Pubertas Prekoks Menurut Hukum Islam

(Analisis Konsep Taklif)

Artinya: Rasulullah Saw menunjukku untuk ikut serta dalam perang Uhud yang ketika itu usiaku empat belas tahun, namun beliau tidak memperbolehkanku, dan kemudian beliau kembali menunjukku pada perang khandak yang ketika itu usiaku lima belas tahun, beliaupun memperbolehkanku. Nafi' (perawi hadith ini) berkata: "Aku menghadap Umar Ibn Abdul Aziz (w.101 H) pada saat itu beliau menjabat sebagai khalifah, kemudian aku menceritakan hadis ini, lalu Umar Ibn Abdul Aziz berkata: Sesungguhnya ini adalah batas antara orang yang masih kecil dan sudah dewasa".

Ada juga Hadis dari Sayyidah Aishah Ra (w.58 H),

لا يقبل الله صلاة امر اة قد حاضت الا بخمار 297

Artinya: Allah Swt tidak menerima salat seorang perempuan yang telah haid kecuali dengan berkurudung. (Hadis riwayat Ibn Huzaimah dan at-Tirmidhi).

Kemudian ada juga hadis yang sangat populer dari Sayyidah Aishah Ra,

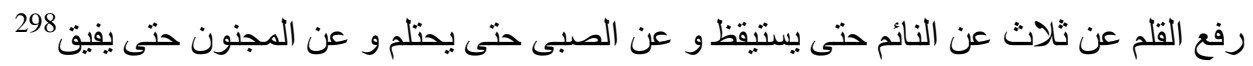

Artinya: "Diangkatlah (dihilangkanlah) pembebanan hukum dari tiga (kategori orang), yaitu orang tidur sampai ia bangun, anak kecil sampai ia balig dan orang gila sampai ia sembuh". (Hadits riwayat Bukhari, Abu Dawud, at-Tirmidhi, anNasai, dan Ibn Majah dari Aisyah dan 'Ali Ibn Abi Talib Radiyallahu 'anhuma).

Melihat kepada semua dalil-dalil ini, maka jelas tanda balig itu adalah keluarnya air mani kali pertama bagi anak laki-laki dan keluarnya haid kali pertama bagi anak perempuan, dan jika seandainya anak laki-laki tersebut tidak keluar air mani ataupun anak perempuan tersebut tidak keluar haid, maka batasan usianya adalah usia genap 15 tahun. Begitu yang disepakati oleh jumhur ulama.

Pertanyaannya adalah mungkinkah konsep taklif ini diberlakukan untuk anak-anak pubertas prekoks. Kalau diberlakukan rasanya sungguh sangat tidak adil sekali. Karena diantara mereka anak pubertas prekoks ini, ada yang keluar air

${ }^{297}$ Al-Hafiz at-Tirmidhi, Sunan at-Thirmidhi, Cet I, Kitab as-Salah, Hadist 337, 121. Bab جاء لا تقبل صلاة امر اة الا بخمار. Hadith ini bercerita tentang tidak sahnya salat seorang permpuan yang sudah haid, jka ia tidak berkerudung. Artinya jika seorang perempuan sudah mendapatkan haid, maka ia sudah diwajibkan salat. http://library.islamweb.net/newlibrary/display book.php?flag=1\&bk no=56\&ID=679

${ }^{298}$ Al-Hafiz at-Tirmidhi, Sunan at-Thirmidhi, Cet I, Kitab al-Hudud, Hadist 1423, 336. Lihat juga Jalal ad-Din as-Suyuti, Sunan an-Nasai bi Sharh al-Hafiz Jalal ad-Din as-Suyuti, Juz VI, Bab Talaq, Hadist 3432, 468. 
ISTIGHNA, Vol. 2, No 1, Januari 2019 P-ISSN 1979-2824

Homepage: http://e-journal.stit-islamic-village.ac.id/index.php/istighna

Aprianif

Pubertas Prekoks Menurut Hukum Islam

(Analisis Konsep Taklif)

mani ataupun haid di usia yang sangat-sangat dini, ada yang di usia 8 tahun, 7 tahun bahkan ada yang di usia 6 tahun. Rasanya tidak mungkin anak sekecil itu dianggap sebagai seseorang yang sudah dewasa, seseorang yang sudah mempunyai tanggungjawab dan kewajiban-kewajiban tertentu. Karena itu, menurut hemat penulis perlu kiranya dicarikan solusi untuk masalah ini, tetapi tentunya dengan melakukan ijtihad.

Menurut Yusuf al-Qardawi, dalam menghadapi berbagai perkembangan zaman hari ini, ijtihad yang bisa dilakukan setidaknya ada dua, yaitu ijtihad intiqai dan ijtihad inshai. Ijtihad intiqai (ijtihad selektif) adalah suatu ijtihad yang dilakukan oleh seseorang atau sekelompok orang untuk memilih pendapat ahli Fiqh terdahulu terhadap suatu masalah tertentu sebagaimana yang terdapat dalam kitab-kitab Fiqh. Tentunya dengan menyeleksi mana pendapat yang lebih kuat dalilnya dan lebih relevan untuk diterapkan dalam kondisi sekarang ini. Dalam hal ini menurut Yusuf al-Qardawi, seorang mujtahid harus bertitik tolak pada empat hal.

Pendapat tersebut lebih relevan diterapkan untuk zaman sekarang.

Pendapat tersebut lebih banyak mencerminkan rahmat bagi umat manusia.

Pendapat tersebut lebih dekat kepada kemudahan yang diberikan syara'.

Dan pendapat tersebut lebih utama dalam merealisir maksud dan tujuantujuan syara', yaitu berupa pencapaian kemaslahatan dan menjauhi kerusakan dari umat manusia. ${ }^{299}$

Ijtihad model ini, sebenarnya bukanlah hal yang baru dalam lapangan ilmu Fiqh perkembangan. Ia dulu sering dan pernah dilakukan oleh Ibn Rusdh (w.594 H) tokoh Fiqh mazhab Maliki dalam bukunya Bidayah al-Mujtahid wa Nihayah al-Muqtasid. ${ }^{300}$ Kemudian ada Shihabuddin al-Qarrafi $(w .684 \mathrm{H})$ tokoh Fiqh madhhab Maliki juga dalam bukunya al-Furuq, dan juga ada Ibn Qudamah

\footnotetext{
${ }^{299}$ Yusuf al-Qardawi, Al-Ijtihad Fi asy-Syari'ah al-Islamiyah Ma'a Nazarat Tahliliyah Fi Ijtihad al-Mu'asir. Diterjemahkan oleh Ahmad Syatori, Ijtihad Dalam Syari'at Islam Dan Beberapa Pandangan Analisi Tentang Ijtihad Kontemporer (Jakarta: Bulan Bintang, 1987), 115.

${ }^{300}$ Muhammad Ibn Rushd, Bidayah al-Mujtahid wa Nihayah al-Muqtasid (Beirut: Dar alJil, 1989).
} 
ISTIGHNA, Vol. 2, No 1, Januari 2019 P-ISSN 1979-2824

Homepage: http://e-journal.stit-islamic-village.ac.id/index.php/istighna

Aprianif

Pubertas Prekoks Menurut Hukum Islam

(Analisis Konsep Taklif)

(w.620 H) tokoh Fiqh madhhab Hanbali dalam bukunya al-Mugni, walaupun memang istilah ijtihad intiqai ini baru muncul belakangan ini. ${ }^{301}$ Dikatakan ketiga tokoh ini melakukan ijtihad intiqai itu disebabkan karena adanya faktor perubahan sosial yang terjadi dalam kehidupan masyarakat pada waktu itu.

Selanjutnya setelah ijtihad intiqai, ada ijtihad insyai (ijtihad kreatif). Ia adalah suatu ijtihad yang mengambil konklusi hukum baru dalam suatu permasalahan yang belum pernah dikemukakan oleh ulama Fiqh terdahulu, baik itu masalah baru ataupun masalah lama. Maksudnya adalah persoalan yang dicarikan hukumnya tersebut bisa persoalan yang benar-benar baru, artinya persoalan tersebut belum pernah ada kasusnya dan hukumnya dalam khazanah keilmuwan Fiqh klasik, ataupun terhadap persoalan lama yang sudah pernah dibahas oleh ulama terdahulu, tetapi mujtahid tersebut melakukan ijtihad dengan memunculkan pendapat yang baru diluar pendapat-pendapat yang sudah ada. ${ }^{302}$

Kemudian beliau juga mengatakan bahwa dalam hal ijtihad insyai ini, terutama di zaman modern ini, untuk memahami, membahas dan meneliti kasuskasus baru yang akan ditentukan hukumnya, maka hal yang paling tepat dilakukan adalah dengan mengumpulkan berbagai ahli yang terkait dengan masalah tersebut. Dengan dikumpulkannya para ahli, bisa mengungkap segala seluk beluk permasalahan yang berhubungan dengan masalah tersebut. Sehingga pada akhirnya kesimpulan hukum yang diambil bisa lebih mendekati kebenaran. Ijtihad ini disebut dengan ijtihad jama'i. Sikap kebersamaan dalam memecahkan suatu kasus oleh berbagai ahli yang terkait. ${ }^{303}$

Melihat kepada dua pembagian ijtihad ini, maka ijtihad yang bisa penulis lakukan dalam masalah konsep taklif ini adalah ijtihad intiqai, yaitu ijtihad

\footnotetext{
${ }^{301}$ Ahmad Ibn Qudamah, al-Mugni (Beirut: Dar Al-Kutub al-Ilmiyah, t.thn). Lihat juga Shihabuddin al-Qarrafi, al-Furuq (Beirut, Dar al-Fikr, 1982).

${ }^{302}$ Dalam kasus ini sebenarnya terdapat perbedaan pandangan ulama Usul Fiqh. Sebagian menyatakan bahwa jika dalam suatu kasus terdapat dua pendapat, mujtahid lain tidak boleh memunculkan pendapat ketiga. Tetapi menurut Yusuf al-Qardawi, patokannya bukanlah pendapatnya, tetapi dalil. Jika seorang mujtahid munshi' menemukan dalil yang baru, maka bisa saja ia memunculkan pendapat yang berbeda dengan pendapat yang sudah ada. Lihat Yusuf alQardawi, Al-Ijtihad Fi asy-Syari'ah al-Islamiyah Ma'a Nazarat Tahliliyah Fi Ijtihad al-Mu'asir. Diterjemahkan oleh Ahmad Syatori, Ijtihad Dalam Syari'at Islam Dan Beberapa Pandangan Analisi Tentang Ijtihad Kontemporer (Jakarta: Bulan Bintang, 1987), 126.

${ }^{303}$ Ali Hasballah, Usul at-Tashri' al-Islami, Cet V (Cairo: Dar al-Ma'arif, 1986), 108
} 
ISTIGHNA, Vol. 2, No 1, Januari 2019 P-ISSN 1979-2824

Homepage: http://e-journal.stit-islamic-village.ac.id/index.php/istighna

Aprianif

Pubertas Prekoks Menurut Hukum Islam

(Analisis Konsep Taklif)

dengan membandingkan berbagai pendapat para ulama terdahulu dalam masalah konsep taklif tersebut dan kemudian disesuaikan, mana kira-kira yang paling maslahat dan paling sesuai dengan kondisi umat hari ini. Karena itu, setelah memperhatikan dan menimbang berbagai pendapat ulama tentang masalah taklif, penulis sepakat dengan apa yang disampaikan oleh imam Nawawi al-Bantani (w.1314 H) di dalam kitabnya Kashifatush Shaja Sharah Safinatun Naja, mengutip pendapatnya imam Syafi'i. Beliau mengatakan,

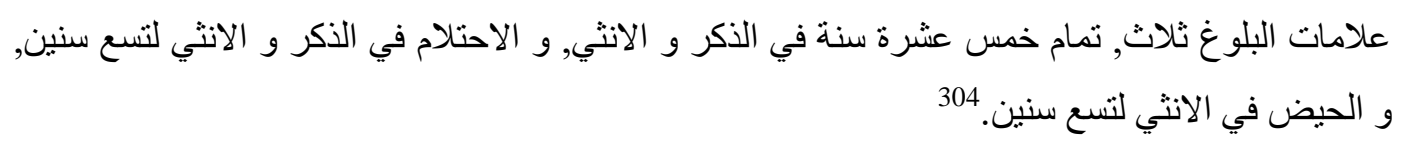

Artinya: Tanda balig itu ada tiga, telah sempurna 15 tahun untuk laki-laki dan perempuan, bermimpi (keluar air mani) untuk laki-laki dan perempuan minimal usia 9 tahun, dan haid bagi perempuan minimal berusia 9 tahun juga.

Dalam kitabnya ini, imam Nawawi al-Bantani mengatakan bahwa ada batasan usia minimal dalam menentukan balig seseorang, dan hal ini sangat krusial menurut penulis. Karena jika batasan usia minimal ini tidak ada, maka akan banyak terjadi kekacauan-kekacauan. Bukankah di dalam mazhab Syafi'i, sebagian mazhab Hanafi dan mazhab Imamiyah batasan usia minimal balig itu memang ada. Ulama mazhab Syafi'i dan sebagian ulama mazhab Imamiyah menyatakan bahwa balig hanya bisa dicapai oleh seseorang ketika ia berusia minimal 9 tahun. Sedangkan sebagian ulama mazhab Hanafi menyatakan bahwa patokan dasar balig itu adalah berusia serendah-rendahnya 12 tahun bagi laki-laki dan berusia serendah-rendahnya 9 tahun bagi perempuan.

Dalam mazhab Syafi'i dikatakan bahwa, batasan usia minimal 9 tahun ini adalah ijtihadnya imam Syafi'i. Setelah melalui استقراع او بحث (penelitian) yang panjang dan melelahkan, yang penuh dengan kehati-hatian dan pertimbangan, imam Syafi'i berijtihad bahwa usia minimal balig itu adalah 9 tahun. Ijtihad yang beliau lakukan, tentunya tidak hanya ijtihad secara dzahiri saja, tetapi juga ijtihad secara bathini, meminta petunjuk kepada al-Hakim, Allah Swt. Karena itu, karena

\footnotetext{
${ }^{304}$ Abu 'Adil Mu'ti Nawawi Ibn Umar Al-Bantani Al-Jawi, Kashifatush Shaja Sharah Safinatun Naja (Beirut: Dar Ibn Hazm, 2011), 39.
} 
ISTIGHNA, Vol. 2, No 1, Januari 2019 P-ISSN 1979-2824

Homepage: http://e-journal.stit-islamic-village.ac.id/index.php/istighna

Aprianif

Pubertas Prekoks Menurut Hukum Islam

(Analisis Konsep Taklif)

penulis adalah seseorang yang bermazhab Syafi'i, pendapat adanya batasan usia minimal balig 9 tahun ini, sangat penulis setujui.

Imam Syafi'i mengatakan bahwa tidak mungkin rasanya seseorang akan mengeluarkan air mani ataupun haid dibawah usia 9 tahun. Jikapun ada, itu sangatlah jarang (nadir), karena memang dimasa beliau kejadian ini bisa hampir dikatakan tidak ada. Itulah sebabnya kenapa, jika ada yang mengeluarkan air mani ataupun haid dibawah usia 9 tahun, menurut imam Syafi'i mereka tetap dihitung belum balig. Bukankah dalam ilmu Fiqh ada sebuah kaedah yang menyatakan bahwa النادر كالاعدام, الاعدام كالمعدوم (yang jarang itu dihitung tiada, dan yang tiada itu ditiadakan). ${ }^{305}$

Kemudian selanjutnya bagaimana dengan masa sekarang ini, apakah batasan usia minimal 9 tahun ini masih berlaku? Andaikan masih berlaku, dan menurut hemat penulis itu masih berlaku, maka artinya anak-anak yang menderita pubertas prekoks jika ia keluar air mani ataupun haid dibawah usia 9 tahun, maka ia dihitung belum balig, tetapi jika ia keluar air mani ataupun haid diatas usia 9 tahun, maka ia dihitung sudah balig. Tidak peduli seperti apapun keadaannya, konsekwensinya ketika ia dihitung sudah balig, tentunya ia sudah dianggap sebagai orang yang sudah dewasa dan pastinya sudah dikenai beban taklif.

Tetapi selanjutnya mungkinkah batasan usia minimal balig ini bisa dirubah, baik ditambah ataupun dikurangi, ataupun mungkin konsep taklif itu sendiri yang dirubah. Untuk menjawab pertanyaan ini, maka perlu tentunya dilakukan ijtihad insya'i, dan penulis tidak mempunyai kemampuan untuk itu. Jika hal ini mungkin dilakukan, maka pastinya ia membutuhkan penelitian yang sangat mendalam. Perlu kesungguhan yang sangat besar dan tentunya dilakukan oleh seseorang yang mempunyai keilmuan yang mumpuni. Setidaknya seseorang yang melakukannya tersebut harus memiliki lima sarat mujtahid, ia mempunyai pengetahuan yang mendalam tentang Al-Quran dan as-Sunnah, mengetahui persoalan-persoalan yang menjadi ijma' ulama terdahulu, mengerti bahasa Arab, mengusai ilmu Usul

\footnotetext{
${ }^{305}$ Asy-Syarbini al-Khatib, Mughni al Muhtaj Sharh al-Minhaj, Juz II, 166-170.
} 
ISTIGHNA, Vol. 2, No 1, Januari 2019 P-ISSN 1979-2824

Homepage: http://e-journal.stit-islamic-village.ac.id/index.php/istighna

Aprianif

Pubertas Prekoks Menurut Hukum Islam

(Analisis Konsep Taklif)

Fiqh, dan memahami maqasid syari'ah (maksud syara' dalam pengsyari'atan hukum). ${ }^{306}$

Selanjutnya ketika ada seseorang yang didalam dirinya terpenuhi syaratsyarat intelektual seorang mujtahid tersebut, maka kemungkinan ijtihad jama'i bisa ia lakukan, yaitu dengan mengumpulkan berbagai ahli yang terkait dengan permasalahan balig ini. Kemudian ditanyakan kepada mereka segala seluk beluknya. Berbagai ahli yang terkait disini tentunya ada ahli Fiqh, Kedokteran, Psikologi, Sosiologi, Hukum, Perkembangan, ahli Gizi, ahli Usul Fiqh dan berbagai ahli lainnya. Kemudian jika seandainya semua hal ini bisa terpenuhi maka penulis akan sangat mengakpresiasi sekali terjadinya ijtihad insya'i ini.

\section{Dalil Mesti Adanya Batasan Usia 9 Tahun Dalam Konsep Taklif}

Menurut penulis diantara dalil-dalil atau alasan-alasan kenapa mesti ada batasan usia 9 tahun dalam konsep taklif adalah:

1. 'Urf

'Urf merupakan dalil utama mesti adanya batasan usia 9 tahun dalam konsep taklif menurut penulis. Sebagaimana diketahui secara bahasa 'urf artinya adalah kebiasaan, segala sesuatu yang baik, baik itu berupa bahasa ataupun tindakan, yang jelas ia berlaku di tengah kehidupan masyarakat dan masyarakat tidak asing baginya. ${ }^{307}$ Pengertian ini bisa dirujuk dalam Al-Quran surat al-A'raf (7) ayat 46 dan surat al-Mursalat (77) ayat 1.

Sedangkan menurut istilah, menurut Muhammad Adib Shalih 'urf adalah مegala sesuatu (baik perkataan ataupun perbuatan) yang telah dikenal dalam suatu masyarakat atau sekelompok orang serta telah mereka sepakati. Al-Jurjani mengatakan bahwa (w.1001 M) 'urf

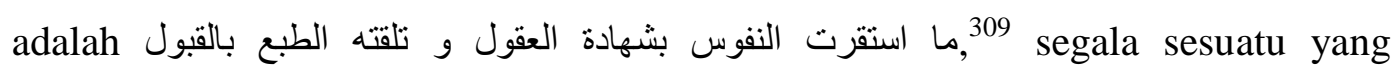
menentramkan jiwa, sesuai dengan pemikiran yang sehat serta dapat diterima

\footnotetext{
${ }^{306}$ Wahbah az-Zuhaili, Usul al-Fiqh al-Islami, Jilid II, 1043-1051.

${ }^{307}$ Muhammad Abu Zahrah, Usul Fiqh, 27. Kemudian bandingkan dengan pengertian 'Urf dari Amir Syarifuddin, Ushul Fiqh, Jilid II, 388. Lihat juga Mustafa Said al-Khin, al-Kafi al-Wafi fi Usul al-Fiqh al-Islami (Beirut: ar-Risalah: 2000), 215.

${ }^{308}$ Muhammad Adib Salih, Masadir at-Tashri' Wa Manahij al-Istimbat (Damasqus: atTa'awuniyah, 1968), 499. Muhammad Adib Salih adalah ketua jurusan Al-Quran dan Sunnah di Universitas Damasqus yang dilahirkan pada tahun 1926 di Damasqus Barat, Syria.

${ }^{309}$ Al-Jurnani, Kitab at-Ta'rifat (Beirut: Maktab Lubnan, 1969), 154.
} 
ISTIGHNA, Vol. 2, No 1, Januari 2019 P-ISSN 1979-2824

Homepage: http://e-journal.stit-islamic-village.ac.id/index.php/istighna

Aprianif

Pubertas Prekoks Menurut Hukum Islam

(Analisis Konsep Taklif)

sesuai dengan tabi'atnya. Sedangkan al-Khayyat mengatakan bahwa 'urf adalah مesuatu yang sudah dikenal oleh sekelompok masyarakat secara luas serta mereka telah membiasakannya di seluruh negeri ataupun sebagiannya.

Merujuk kepada tiga pengertian ini maka jelaslah bahwa 'urf itu sebenarnya adalah suatu perkataan, perbuatan ataupun keadaan yang telah diterima oleh suatu masyarakat sebagai bagian dari kehidupan mereka, ataupun suatu kebiasan yang sudah melekat dan tidak dapat dipisahkan dari kehidupan mereka masyarakat sehari-hari. ${ }^{311}$ Oleh karena itu 'urf ini ada pembagian-pembagiannya. Dilihat dari segi ruang lingkup berlakunya 'urf ini terbagi dua. Ada yang bersifat umum dan ada yang bersifat khusus. 'Urf yang bersifat umum adalah kebiasaan atau keadaaan yang secara merata berlaku untuk atau di semua anggota masyarakat, meskipun berbeda tempat, masa dan budayanya. ${ }^{312}$ Contohnya adalah kebiasaan mempersilahkan orang-orang terhormat untuk mengambil tempat atau makanan terlebih dahulu, ataupun tentang ketentuan pembatasan berat benda bawaan penumpang ke kabin pesawat umpamanya. Ini sudah berlaku di seluruh dunia, meskipun berbeda tempat, waktu dan budaya. Sedangkan 'urf yang bersifat khusus itu adalah kebiasaan-kebiasaan yang berlaku hanya pada sebagian masyarakat saja ataupun pada sekelompok orang saja. Contohnya seperti kebiasaan diantara para

\footnotetext{
${ }^{310}$ Abdul Aziz al-Khayyat, Nazariyat al-'Urf (Amman: Maktabah al-Aqsa, 1977), 21.

${ }^{311}$ Salah satu hal yang sering menjadi perdebatan dikalangan ulama adalah, apakah 'urf ini sama dengan adat. Untuk menjawab itu, maka penulis jelaskan juga disini pengertian adat. Menurut al-Jurjani adat adalah segala sesuatu (baik perkataan ataupun perbuatan) yang secara terus menerus berlaku di tengah kehidupan masyarakat, sesuai dengan penalaran serta dilakukan berulang kali. Sedangkan al-Khayyat mengatakan bahwa adat adalah sesuatu yang dilakukan berulang kali oleh seseorang, khusus ia sendiri yang melakukannya. Karena itu dari pengertian ini bisa dipahami bahwa 'urf itu lebih khusus dari pada adat, karena adat bisa ditujukan untuk kebiasaan yang dilakukan oleh seseorang saja sedangkan 'urf tidak.

Karena itu untuk memisahkan antara adat dan 'urf, al-Khayyat mengemukakan dua konsep al-'Awa'id, yaitu al-'Awa'id al-'Ammah (adat) dan al-'Awa'id al-Mutaghayyirah ('urf). Al-'Awa'id al-'Ammah adalah kebiasaan yang sama meskipun berbeda tempat, keadaan dan waktu, seperti adat makan, minum, dan lain sebagainya. Sedangkan al-'Awa'id al-Mutaghayyirah adalah kebiasaan yang berbeda karena berbeda situasi, kondisi dan tempat, seperti kebiasaan berpakaian, tempat tinggal dan lain sebagainya. Ini pendapat bagi ulama yang membedakan antara 'urf dan adat, walaupun ada juga sebagian ulama yang mengatakan bahwa antara adat dan 'urf sama saja. Lihat Al-Jurnani, Kitab at-Ta'rifat, 154 dan Abdul Aziz al-Khayyat, Nazariyat al-'Urf, 27-28.

${ }^{312}$ Biasanya 'urf yang seperti ini tidak ada seorangpun atau sekelompok masyarakatpun yang menyangkal berlakunya. Lihat Abdul Aziz al-Khayyat, Nazariyat al-'Urf, 33.
} 
ISTIGHNA, Vol. 2, No 1, Januari 2019 P-ISSN 1979-2824

Homepage: http://e-journal.stit-islamic-village.ac.id/index.php/istighna

Aprianif

Pubertas Prekoks Menurut Hukum Islam

(Analisis Konsep Taklif)

petani, kebiasaan diantara pada pedagang, ataupun kebiasaan-kebiasaan pada kelompok-kelompok tertentu. ${ }^{313}$

Kemudian apabila ditinjau dari segi berlaku atau tidaknya suatu 'urf untuk dijadikan sebagai landasan dalam menetapkan suatu hukum, maka 'urf inipun terbagi dua juga. Ada'urf shahih dan ada'urffasid.'Urf shahih adalah ما تعارف الناس مانعارف segala sesuatu yang telah menjadi kebiasaaan dalam suatu masyarakat, dan ia tidak bertentangan dengan ketentuan nass, serta tidak juga menghilangkan kemaslahatan ataupun mendatangkan kerusakan. Maksudnya adalah ketika ada suatu 'urf, suatu tradisi atau suatu kebiasaan, tidak bertentangan dengan Al-Quran dan as-Sunnah, kemudian tidak juga membawa kepada kerusakan dan bahkan mendatangkan kemaslahatan, maka ia bisa dianggap sebagai sesuatu yang sahih atau sesuatu ما خلف بعض ادلة yang benar. Sedangkan'urf fasid, lawan dari 'urf shahih. Ia adalah الشرع او بعض قواعده الاساسية, segala sesuatu (kebiasaan) yang menyalahi sebagian dalil-dalil syara', ataupun sebagian prinsip-prinsip pokoknya syara'. Maksudnya adalah ketika ada suatu 'urf, suatu tradisi atau suatu kebiasaan secara nyata bertentangan dengan nass syara' ataupun bertentangan dengan tujuan-tujuan syara', maka ia bisa dianggap sebagai'urf fasid, 'urf yang tidak benar, dan ia mesti dibuang dan dihapus dalam kehidupan masyarakat. Tanda dari 'urf ini mudah saja, yaitu lihat dari kemudharatan yang diakibatkannya, karena biasanya 'urf fasid selalu akan mendatangkan kemudharatan dan kerugian.

Selanjutnya ketika ada suatu 'urf atau suatu kebiasaan sudah mapan, sudah melekat dalam suatu masyarakat, kemudian didalamnya juga terdapat kemaslahatan dan ia juga sejalan dengan nass dan tujuan-tujuan syara', maka menurut ulama Usul Fiqh, 'urf yang seperti ini bisa dijadikan sebagai bagian dari ketentuan-ketentuan hukum dalam suatu masyarakat. Karena dalam hukum Islam

\footnotetext{
${ }^{313}$ Berbicara tentang 'urf khusus ini, ia biasanya lebih banyak dan lebih bervariasi dari 'urf umum. Hal ini disebabkan karena manusia adalah makhluk sosial yang terdiri dari suku-suku dan bangsa-bangsa. Kemaslahatan dan kebutuhan mereka dalam menjalani hidup tentu berbeda-beda pula, karena itu biasanya kebiasaan-kebiasaan mereka akan berbeda-beda juga. Lihat Abdul Wahab Khalaf, Mas\}adir at-Tashri' fi Ma La Nass fih, 89.

${ }^{314}$ Kemaslahatan disini tentunya adalah kemaslahatan yang sesuai dengan ukuran-ukuran syara'. Lihat Abdul Wahab Khalaf, Ilmu Ushul Fiqh (Jakarta: Al-Majalis al-A'la al-Indonesia li alDa'wah al-Islamiyah, 1972), 146.
} 
ISTIGHNA, Vol. 2, No 1, Januari 2019 P-ISSN 1979-2824

Homepage: http://e-journal.stit-islamic-village.ac.id/index.php/istighna

Aprianif

Pubertas Prekoks Menurut Hukum Islam (Analisis Konsep Taklif)

itu ada suatu kaidah yang berbunyi, العدة محكمة(kebiasaan yang dijadikan hukum). ${ }^{315}$ Contohnya adalah dalam suatu masyarakat, mereka sudah biasa melakukan transaksi jual beli tampa sighat umpamanya. Mereka biasa melakukan transaksi itu dengan cara ta'ati saja, penjual memberikan barang kepada si pembeli dan si pembeli memberikan bayarannya dan menerima barangnya, tampa ada ucapan ijab qabul. Maka jika kebiasaan seperti ini sudah melekat pada suatu masyarakat, maka kebiasaan itu bisa dijadikan sebagai bagian dari hukum Islam dalam masyarakat tersebut. Sehingga ketika mereka melakukan transaksi jual beli, itu cukup hanya dengan cara ta'ati saja, transaksinya dihitung $s a h .{ }^{316}$ Dan untuk konsep taklif ini, menurut hemat penulis kaidah العدة محكمة juga berlaku kepadanya. Ketika ada seorang Hakim umpamanya, ingin menentukan apakah seseorang sudah taklif dalam suatu masyarakat atau belum, maka perlu kiranya baginya untuk memperhatikan'urf taklif dalam masyarakat tersebut. Karena jika tidak, maka bisa saja ia keliru. Bisa saja ada seorang anak yang sepertinya kelihatannya sudah taklif mungkin karena sudah menstruasi atau keluar air mani, tetapi dalam kenyataannya ternyata menstruasi atau keluar air maninya itu disebabkan oleh berbagai macam faktor yang mempengaruhinya, bisa jadi menstruasi atau keluar air maninya itu tidak murni benar-benar menstruasi atau keluar air mani, dan ini bisa saja terjadi. Apalagi di zaman modern ini, banyak keanehan-keanehan dan problematika-problematika yang berkembang di masyarakat. Karena itu menurut hemat penulis dalam masalah konsep taklif perlu sekali untuk memperhatikan 'urf.

Selanjutnya ketika berbicara tentang 'urf, maksudnya 'urf taklif, ulama Syafi'iyah dan Imamiyah sudah mengatakan bahwa, sebagaimana yang sudah penulis jelaskan sebelumnya, minimal usia taklif itu'urfan (secara 'urf) adalah usia 9 tahun. Karena itu jika ada yang menstruasi atau keluar air mani di bawah usia 9 tahun itu bisa dihitung belum taklif. Selain itu kalaupun ada yang benar-benar keluar air mani ataupun haid dibawah usia 9 tahun itu sangatlah jarang, dan ketentuannya yang jarang dalam hukum Islam, itu tidak bisa dijadikan patokan

\footnotetext{
${ }^{315}$ Nasrun Haroen, Ushul Fiqh 1, 143.

${ }^{316}$ Abdul Wahab Khalaf, Masadir at-Tashri' fi Ma La Nass fih, 89.
} 
ISTIGHNA, Vol. 2, No 1, Januari 2019 P-ISSN 1979-2824

Homepage: http://e-journal.stit-islamic-village.ac.id/index.php/istighna

Aprianif

Pubertas Prekoks Menurut Hukum Islam (Analisis Konsep Taklif)

hukum, النادر لا حكم له (yang jarang terjadi, tidak ada hukum baginya). Kaidah lain cabang dari العدة محكمة juga mengatakan الحكم بالمعتاد لا بالنادر (hukum itu mencakup apa yang biasa terjadi, bukan apa yang jarang terjadi).

\section{Adanya Dimensi Hikmah dan Maslahah}

Selanjutnya dalil kedua tentang mesti adanya batasan usia 9 tahun dalam konsep taklif setelah 'urf adalah adanya dimensi hikmah dan maslahah. Perlu diketahui bahwa dijadikannya 'urf sebagai suatu bagian dari hukum Islam itu sebenarnya tidak lain adalah merupakan perwujudan dari kemaslahatan. Karena ketika ada suatu 'urf, yang mana ia tidak bertentangan dengan nass, maka biasanya didalamnya mesti terdapat kemaslahatan, dan ketika didalamnya terdapat kemaslahatan, maka disana tentu ada keridhaan Allah Swt. Ahmad al-Zarqa' pernah mengatakan حيثما وجدت المصلحة فثم وجه الله kemaslahatan maka disana akan ditemukan keridhaan Allah Swt. Itu jugalah kenapa dalam masalah perubahan dan adaptasi hukum dalam hukum Islam, dimensi hikmah dan maslahah dikatakan biasanya selalu bisa menyediakan ruang untuk perubahan hukum. ${ }^{318}$

Selanjutnya ketika dikatakan dimensi hikmah dan maslahah dapat dijadikan sebagai salah satu metode pendekatan dalam perubahan hukum, maka yang dimaksud dari hikmah dan maslahah disini tentunya adalah hikmah dan maslahah yang sesuai dengan maqasid ash-Syari'ah, atau kalau dalam bahasanya Ibn Qayyim al-Jauziyyah, ar-Ruh ash-Syari'ah. Karena itu seorang mujtahid diharapkan tidak hanya terpaku pada bentuk formal suatu permasalahan hukum, tetapi ia juga mesti menggali hikmah dan maslahah dari suatu permasalahan hukum tersebut. Karena sebagaimana diketahui bersama bahwa tujuan hukum Islam itu diturunkan atau fondasi dasarnya adalah kemaslahatan bagi seluruh umat manusia.

\footnotetext{
${ }^{317}$ Ahmad al-Zarqa', al-Madkhal al-Fiqh al-'Am (Damaskus: Dar al-Fikr, 1968), 863.

${ }^{318}$ Hikmah ada yang mengartikan sama atau sinonim dengan filsafat. Namun Rashid Rida mendefinisikan bahwa hikmah itu adalah suatu ilmu tentang kebenaran yang menyebabkan kehendak untuk melakukan sesuatu yang bermanfaat karena didalamnya mengandung pemahaman secara mendalam tentang permasalahan hukum dan asrar persoalan. Lihat Muhammad Rashid Rida, Tafsir al-Manar, Jilid III (Beirut: Dar al-Ma'arif, t.thn), 310.
} 
ISTIGHNA, Vol. 2, No 1, Januari 2019 P-ISSN 1979-2824

Homepage: http://e-journal.stit-islamic-village.ac.id/index.php/istighna

Aprianif

Pubertas Prekoks Menurut Hukum Islam

(Analisis Konsep Taklif)

Disinilah letaknya keadilan Allah Swt. Karena itu, segala upaya untuk mencapai kemaslahatan yang merupakan keadilan Allah mesti disyari'atkan, dan dimana saja keadilan Allah ditemukan, maka disana ada hukum Allah Swt. ${ }^{319}$

Selanjutnya apa hikmah dan maslahah jika taklif dalam hukum Islam itu dibatasi dengan batasan usia 9 tahun. Menurut hemat penulis pasti akan ada banyak hikmah dan maslahah di dalamnya. Usia 9 tahun adalah usia yang sudah cukup mapan menurut penulis. Bukankah para ulama sudah sepakat mengatakan bahwa ketika anak sudah berusia 7 tahun maka ia disebut dengan mumayyis, bisa membedakan mana yang benar dan mana yang salah. Karena itu ketika ada seorang anak sudah mengeluarkan air mani ataupun haid di usia 9 tahun, maka biasanya ia sudah cukup pandai dan cakap dalam menghadapi kehidupannya. Bukankah dikatakan didalam sejarah bahwa sayyidah Aishah Ra tinggal serumah dengan Rasulullah Saw itu di usia 9 tahun.

Selain itu hikmah yang nyata dan jelas-jelas tampak dengan pembatasan usia taklif dengan minimal usia 9 tahun tersebut adalah orang tua bisa menyiapkan pendidikan agama yang baik bagi anak-anaknya sebelum usia tersebut. Sehingga ketika anak-anak mereka sudah mentruasi atau mimpi basah di usianya yang 9 tahun, mereka sudah siap dan sudah mengetahui kewajiban-kewajiban agama yang dibebankan kepadanya sebagai seorang muslim sejati tentunya.

Karena itu orang tua harus mengajarkan kepada anak-anaknya tentang iman (iman kepada Allah, iman kepada Rasul-Nya, iman kepada Malaikat-Nya, iman kepada Kitab-Nya, iman kepada hari Kiamat-Nya serta iman kepada qada dan qadar-Nya. Orang tua juga mesti mengajarkan kepada anak-anaknya tentang masalah ibadah seperti taharah (bersuci), salat, puasa, zakat dan lain sebagainya. Bahkan dalam masalah salat, Rasulullah Saw pernah bersabda,

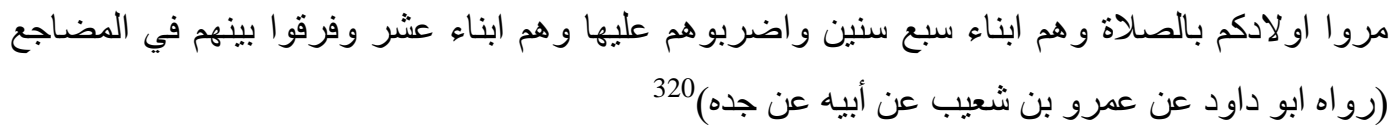

\footnotetext{
${ }^{319}$ Ibn Qayyim al-Jauziyyah, I'lam al-Muwaqqi' in 'an Rabb al-Alamin, Juz III, 3.

${ }^{320}$ Hadis Sahih riwayat Ibn Abi Shaibah. Lihat Sunan Abu Daud no 418. Imam an-Nawawi mengatakan hadis ini hasan. Lihat Muchlis M Hanafi, dkk, Pendidikan, Pembangunan Karakter dan Pengembangan Sumber Daya Manusia (Tafsir Al-Quran Tematik) (Jakarta: Lajnah Pentashihan Mushaf Al-Quran, 2010), 222-223.
} 
ISTIGHNA, Vol. 2, No 1, Januari 2019 P-ISSN 1979-2824

Homepage: http://e-journal.stit-islamic-village.ac.id/index.php/istighna

Aprianif

Pubertas Prekoks Menurut Hukum Islam

(Analisis Konsep Taklif)

Artinya: Suruhlah anak-anakmu salat ketika mereka berusia tujuh tahun, dan pukullah mereka ketika berusia sepuluh tahun, dan pisahkanlah mereka dari tempat tidurnya. (HR, Abu Dawud dari 'Amr ibn Syu'aib).

Karena itu, untuk saat ini, pembatasan usia minimal 9 tahun menurut hemat penulis adalah konsep yang paling sesuai, paling mas\}lah\}ah, paling relevan untuk diterapkan, paling mencerminkan rahmat bagi umat manusia, paling dekat kepada kemudahan yang diberikan syara' dan paling utama dalam merealisir maksud dan tujuan-tujuan syara'.

\section{E. Penutup}

Kesimpulan dari penelitian ini adalah munculnya fenomena pubertas prekoks tidaklah merubah konsep taklif yang sudah ada dalam hukum Islam. Konsep taklif yang mana bisa ditentutan dengan dua keadaan yaitu ketika seseorang sudah mampu memahami khitab syar'i dan ketika ia sudah ahli atau layak untuk menerima beban taklif (sudah balig) tidaklah berubah. Dan kesepakatan jumhur Ulama yang mengatakan bahwa batasannya adalah keluarnya air mani kali pertama bagi anak laki-laki dan keluarnya haid kali pertama bagi anak perempuan, dan kemudian jika seandainya air mani ataupun haid tersebut tidak keluar, maka batasan usia yang dipakai adalah usia genap 15 tahun tetaplah berlaku.

Tetapi kemudian konsep dasar taklif ini demi kemaslahatan dan keadilan, mesti diberikan batasan, dan ini sesuai dengan pendapat imam Syafi'i Rahimahullah yang mengatakan bahwa mesti ada batasan usia minimal dalam balig seseorang, dan beliau sudah menetapkan bahwa batasan usia minilmal tersebut adalah usia 9 tahun. Karena itu jika ada seorang anak yang sudah keluar air mani atau menarche diusia dibawah 9 tahun, maka ia dihitung belum balig.

Pendapat ini menurut penulis adalah pendapat yang paling sesuai, paling maslahah, paling relevan diterapkan, paling mencerminkan rahmat bagi umat manusia, paling dekat kepada kemudahan yang diberikan syara' dan pastinya paling utama dalam merealisir maksud dan tujuan-tujuan syara'.

Tetapi selanjutnya, batasan ini ataupun konsep ini, bukanlah merupakan suatu keputusan final, ia masih bisa berubah, tetapi tentunya perubahan tersebut 
ISTIGHNA, Vol. 2, No 1, Januari 2019 P-ISSN 1979-2824

Homepage: http://e-journal.stit-islamic-village.ac.id/index.php/istighna

Aprianif

Pubertas Prekoks Menurut Hukum Islam

(Analisis Konsep Taklif)

dilakukan oleh seorang mujtahid munsi. Jika ada seorang mujtahid munsi yang ingin merubah konsep ini umpamanya, maka itu adalah hal yang sangat bagus sekali, tetapi pastinya dalam hal ini akan ada banyak pertimbangan dan berbagai ahli yang akan terlibat. At-Taharrur al-Fikr (kebebasan berfikir) dan berijtihad itu selalu terbuka kepada siapapun, tetapi tentunya terhadap persoalan-persoalan yang tidak ada nass-nya dan persoalan-persoalan yang termasuk kedalam kategori zanniyat.

\section{Daftar Pustaka}

\section{Buku}

Abdullah Ibn Ahmad Ibn Qudamah, Raudah an-Nadir, Riyad: Jami'ah al-Imam Muhammad Ibn Su'ud, 1399 H.

Abdul Hay 'Azb Abdul 'Al, Usul al-Fiqh al-Muyassar, Cet II, Cairo: Universitas Al Azhar, 2006.

Abdul Aziz al-Bukhari, Kashf al-Asrar, Jilid II, Beirut: Dar al-Fikr, 1982.

Abdul Aziz al-Khayyat, Nazariyat al-'Urf, Amman: Maktabah al-Aqsa, 1977.

Abdul Wahab Khalaf, Ilmu Ushul Fiqh, Jakarta: Al-Majalis al-A'la al-Indonesia li al-Da'wah al-Islamiyah, 1972.

Abuddin Nata, Abdur Rahman Dahlan, Muhammad Amin Suma, Ahmad Thib Raya dan kawan-kawan, Ensiklopedi Hukum Islam, Jakarta: PT Ichtiar Baru Van Hoeve, 1999.

Abu 'Isha at-Tirmidhi, Sunan at-Tirmidhi, Beirut: Dar al-Kutub al-'Ilmiyyah, t.thn. Abu 'Adil Mu'ti Nawawi Ibn Umar Al-Bantani Al-Jawi, Kashifatush Shaja Sharah Safinatun Naja, Beirut: Dar Ibn Hazm, 2011.

Abu Abdillah Muhammad Ibn Ahmad al-Qurtubi, al-Jami' li Ahkam Al-Qur'an, Jilid V, Beirut: Dar al-Fikr, t.thn.

Abu Bakar Muhammad al-Sarakhsi, Usul al-Sarakhsi, Jilid II, Beirut: Dar alKutub al-'Ilmiyyah, 1983.

Abu Hamid al-Ghazali, al-Mustasfa fi 'Ilmu al-Usul, Jilid I, Beirut: Dar al-Kutub al-'Ilmiyyah, 1983.

Abu Ishak as-Sairazi, Al-Muhadhdhab, Juz I, Cairo: Mathba'ah al-Bab al-Halabi, t.thn. 
ISTIGHNA, Vol. 2, No 1, Januari 2019 P-ISSN 1979-2824

Homepage: http://e-journal.stit-islamic-village.ac.id/index.php/istighna

Aprianif

Pubertas Prekoks Menurut Hukum Islam

(Analisis Konsep Taklif)

Abu Zakariya Muhyuddin An-Nawawi, Sahih Muslim bi Sharah An-Nawawi, Juz XIII, Beirut: Darul Khair, 1994.

Ad-Dardiri, Al-Sharah al-Kabir Hashiyah Dasuki, Jilid III, Cairo: Matba'ah alBab al-Halabi, t.thn.

Ahmad al-Zarqa', al-Madkhal al-Fiqh al-'Am, Damaskus: Dar al-Fikr, 1968.

Ahmad Syatori, Ijtihad Dalam Syari'at Islam Dan Beberapa Pandangan Analisi

Tentang Ijtihad Kontemporer, Jakarta: Bulan Bintang, 1987.

Agnes Tri Harjaningrum Dkk, Peranan Orang Tua Dan Praktisi Dalam

Membantu Tumbuh Kembang Anak Berbakat Melalui Pemahaman Teori

Dan Tren Pendidikan, Jakarta: Prenada Media Group, 2007.

Ali Hasballah, Usul at-Tashri' al-Islami, Cet V, Cairo: Dar al-Ma'arif, 1986.

Asy-Syarbini al-Khatib, Mughni al-Muhtaj Sharah al-Minhaj, Juz II, Cairo: Mathba'ah al-Bab al-Halabi, t.thn.

Behrman RE, Kliegman RM, Jenson HB, Nelson Textbook of Pediatrics, Edisi 17, Philadelphia: Saunders Elsevier Science, 2004.

Didin Hafidhudin, Islam Aplikatif, Jakarta: Gema Insani Press, 2003.

Elizabeth B Hurlock, Psikologi Perkembangan: Suatu pendekatan Sepanjang Rentang Kehidupan, Edisi 5, Jakarta: Erlangga, 1980.

FJ Monks, AMP Knoers, Siti Rahayu Haditono, Psikologi Perkembangan: Pengantar Dalam Berbagai Bagiannya (Yogyakarta: Gadjah Mada University Press, 2002), 263.

Ginarhayu, "Analisis Faktor-Faktor Yang Berhubungan Dengan Usia Menarche Remaja Putri (9 - 15 Tahun) Pada Siswi Sekolah Dasar dan Sekolah Lanjutan Tingkat Pertama di Jakarta Timur”, 2001. Tesis Ginarhayu di Universitas Indonesia. Lihat http://www.digilib.ui.edu/opac/themes/libri2/detail.jsp?id=71129\&lokasi=lo kal.

Ibn 'Abidin, Hashiyah Rad al-Mukhtar 'ala Daur al-Mukhtar, Jilid V, Cairo: AlBab al-Halabi, t.thn. 
ISTIGHNA, Vol. 2, No 1, Januari 2019 P-ISSN 1979-2824

Homepage: http://e-journal.stit-islamic-village.ac.id/index.php/istighna

Aprianif

Pubertas Prekoks Menurut Hukum Islam

(Analisis Konsep Taklif)

Jhon W Santrock, Remaja, Edisi Kesebelas, Jakarta: Erlangga, 2007.

Diterjemahkan oleh Benedictine Widyasinta dengan judul asli Adolescence, Eleventh Edition.

Julia Maria van Tiel dalam buku Julia Maria van Tiel, Anakku Terlambat Bicara (Anak Berbakat dengan Disinkronitas Perkembangan: Memahami, Mengasuhnya, Membedakannya dengan Autisme, ADHD, dan Permasalahan Gangguang Belajar), Edisi 1, Cet 2, Jakarta: Prenada Media Group, 2008.

Muchlis M Hanafi, dkk, Pendidikan, Pembangunan Karakter dan Pengembangan Sumber Daya Manusia (Tafsir Al-Quran Tematik), Jakarta: Lajnah Pentashihan Mushaf Al-Quran, 2010.

Muhammad Adib Salih, Masadir at-Tashri' Wa Manahij al-Istimbat, Damasqus: at-Ta'awuniyah, 1968.

Muhammad Ibn Ali Ibn Muhammad ash-Syaukani, Irshad al-Fuhul ila Tahqiq alHaq min 'Ilmi al-Usul, Cairo: Dar as-Salam, 2006.

Muhammad Ibn Rushd, Bidayah al-Mujtahid wa Nihayah al-Muqtasid, Beirut: Dar al-Jil, 1989.

Muhammad Rashid Rida, Tafsir al-Manar, Jilid III, Beirut: Dar al-Ma'arif, t.thn.

Muhibullah Ibn Abdush Shakur, Musallam ats-Tsubut, Jilid I, Beirut: Dar alKutub al-'Ilmiyah, 1983.

Mustafa Said al-Khin, al-Kafi al-Wafi fi Usul al-Fiqh al-Islami, Beirut: arRisalah: 2000.

Pebri Warita Pulungan, "Gambaran Usia Menarche Pada Remaja Putri di SMP Shafiyyatul Amaliyah dan SMP Nurul Hasanah Kota Medan Tahun 2009". Fakultas Kedokteran Universitas Sumatra Utara http://repository.usu.ac.id/bitstream/123456789/14263/1/09E02903.pdf.

Proverawati A dan Misaroh S, Menarche menstruasi pertama yang penuh makna, Yogyakarta: Muha Medika, 2009.

Sudirman Burhanuddin, "Beberapa Variabel yang Berpengaruh terhadap Usia Menarche Pelajar Putri Bugis Kota dan Desa di Sulawesi Selatan (Suatu Pendekatan Antropologi Ragawi Ditinjau dari Aspek Biologis dan 
ISTIGHNA, Vol. 2, No 1, Januari 2019 P-ISSN 1979-2824

Homepage: http://e-journal.stit-islamic-village.ac.id/index.php/istighna

Aprianif

Pubertas Prekoks Menurut Hukum Islam

(Analisis Konsep Taklif)

Lingkungan Tahun 2007". Tesis Sudirman Burhanuddin di Unair. Lihat http://www.adln.lib.unair.ac.id/.

Saifuddin al-Amidi, al-Ihkam fi Usul al-Ahkam, Beirut: Dar al-Kutub al'Ilmiyyah, 1983.

Teguh Prasetyo dan Abdul Halim Barkatullah, Politik Hukum Pidana, Yogyakarta: Pustaka Pelajar, 2005.

Wahbah az-Zuhayli, al-Fiqh al-Islami wa Adillatuh, Juz IV, Beirut: Dar al-Fikr, 1989.

\section{Jurnal}

B Nazario, "WebMD Medical News", Vol 24, Cadernos De Saude Publica: 2002.

Mayo Clinic Staff, "Precocious Puberty", Mayo Foundation, Diunduh 12

Desember 2012 dari http://mayoclinic.com/article/precociouspubertydefinition. December $12^{\text {th }} 2012$.

PH Whincup, JA Ghil, K Odoki, Taylor SDC, DG Cook, "Age of Menarche in Contemporary British Teenagers: Survey of Girls Born Between 1982 and 1986" (BMJ: 2001), 322:1095-1096. Lihat http://www.ncbi.nlm.nih.gov/pmc/articles/PMC31261/.

Usman Said, "Interaksi Hormonal dan Kualitas Kehidupan Pada Wanita", Diseminarkan pada simposium pengaruh hormonal pada kualitas kehidupan, Dies natalis FK UNSRI ke 42, Palembang 2 Oktober 2004.

Delemarre Van de Waal, Central Regulation of Human Puberti, Disertasi di Vrije Universiteit te Amsterdam, 1984. Lihat juga Jose RL Batubara, Adolescent Development (Perkembangan Remaja), Departemen Ilmu Kesehatan Anak RSCM dan Universitas Indonesia, Seri Pediatri, Vol XII, No I, Juni 2010. http://www.scribd.com/doc/244707171/jurnal-pubertas-normal-pdf\#scribd.

JL Fahmi, JK Kaminsky, F Kaufman, MD Nelson, MT Parisi, The Radiological Approach to Precocious Puberty, The British Journal of Radiology, Vol 73, 560-567, 2000. Diakses dari http://bjr.birjournals.org/cgi/reprint/73/869/560.pdf.

Styne DM, Puberty, Dalam Greenspan FS, Basic and Clinical Endrocrinology 3, Edisi III, San Fransisco: Lange, 1992. 
ISTIGHNA, Vol. 2, No 1, Januari 2019 P-ISSN 1979-2824

Homepage: http://e-journal.stit-islamic-village.ac.id/index.php/istighna

Aprianif Pubertas Prekoks Menurut Hukum Islam (Analisis Konsep Taklif)

Jose RL Batubara, Gonadothropin-releasing hormone agonist as a treatment of choice for central precocious puberty, Pediatric Endocrinology, Pediatric Department FKUI-RSCM, Jakarta, November 2004, Vol 19, No 4.

Haslam RHA, Endokrine System, Dalam Behrman RE, Kliegman RM, Jenson HB, Nelson Textbook of Pediatrics, Edisi XXVII, Philadelphia: Saunders Elsevier Science, 2004.

Paul B Kaplowitz, Precocius Puberty, Medscape Team of Medician, diakses 2 September 2015. Lihat http://emedicine.medscape.com/article/924002overview

http://health.detik.com/read/2011/11/24/123350/1774689/1202/ibu-termudadalam-sejarah-melahirkan-saat-usia-5-tahun.

http://library.islamweb.net/newlibrary/display_book.php?flag=1\&bk_no=56\&ID= $\underline{679}$ 